\title{
The Role of Contrastive Analysis in Translation Study
}

\author{
Sukirmiyadi* \\ The writer is a lecturer of Pembangunan Nasional University (UPN) 'Veteran' East Java Jalan Raya Rungkut \\ Madya, Gunung Anyar - Surabaya, Indonesia \\ *Corresponding Author: Sukirmiyadi, The writer is a lecturer of Pembangunan Nasional University \\ (UPN) 'Veteran' East Java Jalan Raya Rungkut Madya, Gunung Anyar - Surabaya, Indonesia
}

\begin{abstract}
In foreign language teaching and learning process, comparing the two languages between the source language and target language being learnt can not be avoided. According to Carl James, (1980:3), Contrastive Analysis is a linguistic enterprise aimed at producing inverted two-valued typologies, and founded on the assumption that languages can be compared. Meanwhile (Baker, 1998:48) said that contrastive analysis might also provide some explanations of difficulties encountered by a translator in translation. In line with these two statements, it could be assumed that contrastive analysis is closely related to translation study due to the fact that in translation activity, a translator has to compare the two lang uages, source language and target language. This study aims at describing the relationship between contrastive analysis and translation study. Based on the study analysis, contrastive analysis could be classified into 2 (two) main categories, they are micro linguistic contrastive and macro linguistic contrastive. The first contrastive referred to the language study which is analyzed in accordance with the rule and structure of the language itself. Meanwhile the second one is concerned with the relationship between the language and some other related factors, such as in analyzing the text or discourse. A study on contrastive analysis is also required in language teaching, evaluation and research and translation as well. Furthermore, the relationship between contrastive analysis and translation study was bidirectional. On the other hand, the translation of specific pieces of text might provide the data for contrastive analysis. Therefore, a translator would not find if difficult to do translating a text if the source text being translated had similarities of its linguistic aspects with those of the target one.
\end{abstract}

Keywords: Contrastive Analysis, Linguistic contrastive, Compare, Translation Study

\section{INTRODUCTION}

The science of Contrastive Analysis (CA) was at first introduced after the World War II. At that time $\mathrm{CA}$ was intended to support the teaching and learning process of the second or foreign language. This science was required because during that period there was a great urbanization from one country to another, especially European countries. This condition made those immigrants have to learn the new language of that country. In this case they had to be capable of adjusting not only with the new language but also some other things, such as social community and culture which were not formally used and experienced before. Therefore, learning a second or foreign language was a must for them if they wanted to be accepted as the new comers of community where they lived in. Furthermore, during their new language learning, they required some guidance or teachers to help them. This fact made the linguists and scholars conduct some researches or studies in efforts to know the development and acquisition of the new language being learnt by comparing the two languages, the learner's own language and the second or foreign language being learnt. This condition finally brought out a science of 'Contrastive Analysis'. Realizing how important the science of contrastive analysis in terms of second or foreign language learning was, the year 1960s became the beginning of books' publication and other linguistic works, most of which were books of contrastive analysis and translation works. Therefore, in those kinds of books, most of the writers studied and analyzed the languages by comparing the two languages, English as a source language and the other languages in the world especially those of European languages such as Germany, French, Polish and Spain. Besides, they also conducted some teaching programs dealing with second languages in accordance with the new country where they lived. Due to the publishing of many books of contrastive analysis and many scholars conducted many kinds of researches dealing with contrastive analysis (comparing the first and second language), that decade was said to be a 'booming period' of contrastive analysis. 
Furthermore, in line with comparing the two languages, translation activity in that decade could not be avoided. Therefore, translation activity was also becoming another important thing to consider because this activity was always dealing with the first language as a source text to be translated and the second one as a target text, as a translation product. However in general, we have to realize that the two languages usually have either some similarities or differences. Due to these factors, contrastive analysis is required much to analyze a translation product. As it was stated by Lado (1966) that the plan of the book rested on the assumption that we could predict and describe the patterns that would cause difficulty in learning, and those that would not cause difficulty, by comparing systematically the language and culture of the learners. Based on this statement it might be assumed that by conducting CA or comparing the two languages systematically we will be capable of predicting and describing some certain patterns that might make the learners find it easy or difficult to learn the target language.

As what it was stated by James (1980: 3) that Contrastive analysis was always concerned with a pair of languages, and founded on the assumption that languages could be compared. Meanwhile, Richards and Platt (1993) said that Contrastive Analysis was a comparison of linguistic system which was studied in the two languages, such as sound or grammatical system. In accordance with these two definitions, it could be assumed that CA was closely related to comparison process dealing with several aspects available in the two languages in efforts to get to know either their similarities or differences. Several aspects to compare are those from the smallest variation of linguistic aspect, such as sound to the biggest one, that is a discourse. According to Lado in Mooryati (2004:48), it was stated that the comparison result of the two languages was meant to provide some comprehension dealing with practical needs like teaching and learning, translation study and further researches. This statement shows that the science of CA is quite essential to learn and study.

\section{SCOPES OF CONTRASTive ANALYSIS}

In accordance with its linguistic aspects to compare, there are 2 (two) kinds of contrastive analysis: micro linguistic contrastive analysis and macro linguistic contrastive analysis, (Karl James, 1980: 61). Micro linguistics is a science of language that learns a language viewed from the internal side which is analyzed in accordance with its rule or structure of its own language. Therefore, micro linguistic contrastive analysis is meant as a contrastive analysis to the linguistic rule or structure which is limited to the sentence level, such as phonology, grammatical and lexicology aspect. To conduct contrastive analysis, we have to compare the two systems of sound, two grammatical structures, two lexical systems and two writing systems of the two languages to compare, source language and target language. For example, to analyze the phonemic aspect, there are several questions to answer: (a) Does the source language have the same phoneme as the phoneme that the target language has?; (b) Do the two languages to compare have the same variants of phoneme?; (c) Does the phoneme and its variants have the same distribution to the two languages to be compared?

Meanwhile, macro linguistics is a linguistic field which learns one language related to some factors of outer language which is usually conducted above the sentence level. Therefore, in macro linguistic contrastive analysis, its scope is covering contrastive analysis dealing with a language related to the outer factors of a language, like text and discourse analysis. In general, either discourse or text level, some aspects to be compared are in accordance with its similarities and differences in terms of revealing its language functions between the source language and target one. Furthermore, based on its function, there are 3 (three) levels of speech: formal, informal and intimate (intimacy). Therefore, we have to be capable of differentiating a speech used in a formal, informal or intimate situation.

\section{SOME BENEFITS OF CONTRASTIVE ANALYSIS}

In line with the introduction stated previously, here are several benefits of Contrastive Analysis:

- It was stated that contrastive analysis was required in terms of either the second or foreign teaching and learning process with the consideration, if the aspects of the two languages (the first and the second language) to be compared have the same characteristics, this would make the learners easier to learn the target language. On the other hand, if the linguistic aspects to be compared are different, they will make the learners more difficult to learn the target language, Lado in Mooryati (2004:54).

- Besides, contrastive analysis is beneficial in efforts to provide evaluation, research general comprehension of a language to be compared. In line with teaching activity, a teacher who is 
to do comparing between source language and target language, he will know the teaching problems encountered by his students and then is trying to overcome those problems so that he can teach his students better, for example by changing the teaching method, technique, media or the materials which seem to be more appropriate with his student's interest and capability. Therefore, in efforts to know whether the teaching and learning process is successful or not, before teaching a teacher should make a well-prepared both the material to teach and its appropriate teaching technique or media. Besides, if necessary a teacher should also prepare some supplementary materials and is requested to make evaluation and diagnose difficulties and problems encountered by his students.

- Furthermore, contrastive analysis is also useful as a basic instrument of evaluation making. As it was stated previously that having conducted a comparison study between the target language and the first language of the teacher, finally he can detect and find difficulties encountered by his students. This can be used by a teacher as the bases of finding ways or solution dealing with the most appropriate and accurate solution to evaluate those difficulties.

- Based on several researches which had ever been conducted by the former researchers, the research result in accordance with contrastive analysis, would be very beneficial for the coming researchers to conduct the similar researches. Some aspects required which are considered as an important and relevant theories which had not been discussed and analyzed in advance could be used as their bases to complete their new researches.

- The last benefit is dealing with general or public comprehension. Other people, especially the readers and the learners may use the research result of contrastive analysis in efforts to avoid misunderstanding or misperception that might happen between the learners who are reading or speaking in the target language and the other people or native speakers who speak using the target language being learnt. This might happen due to the fact that many of words or terms in the first language cannot be found their equivalent in the target language. The other reason is that both the users of the first and the target language have different cultural background which can influence their language being used.

\section{The Relationship Between Contrastive Analysis and Translation Study}

Above all, there is another more specific thing which is also considered to be very important, that is translation study. However, translation study cannot be separated from the role of contrastive analysis. Ideally therefore, a researcher's capability of both the first and target language mastery who conducts a study on contrastive analysis to a translation result should have an equivalent competence. In other words, it could be assumed that both contrastive analysis and translation result are the two things which cannot be separated each other. As it was stated by Baker (1998: 49), that the relationship between contrastive analysis and translation was bidirectional. On the one hand, the translation of specific pieces of text might provide the data for contrastive analysis. On the other, contrastive analysis might provide explanations of difficulties encountered in translation. Furthermore, James (1980: 4) also said that the first and second (target) language dealing with the translation activity from one language to another, both those two different languages were involved, or a study of how a text from one language was transformed or changed into comparable text in another language.

In line with those two statements, both the first and second (target) languages cannot be separated each other (dependent). Therefore, a translation result as a main source of data is very meaningful in accordance with contrastive analysis. For example, to analyze a translation result of 'Harry Potter', it could be viewed from several linguistic aspects by comparing the two languages between English as the first language and Indonesian as the second language, such as their syntactic equivalent, meaning of lexicon and coherence of discourse. Based on these 3 (three) translation aspects, a translation result is then analyzed accurately and deeply so that several strengths and weaknesses can be found. Then, there should be a right way and appropriate solution to overcome the weaknesses found. Finally, based on the result findings, the researcher can give some positive feedback and or suggestions for improvement and development for the further and better research.

\section{DISCUSSION}

Below is an example of contrastive analysis to the translation result by comparing the two languages: source language and target language. English as a source text and Indonesian as a target text in efforts to see the relationship between contrastive analysis and translation study. 


\begin{tabular}{|c|c|}
\hline Source Text (English) & *Target Text (Indonesian): \\
\hline (a)Welcome, Fren! & (a) Selamat Bergabung, Fren! \\
\hline (b) Thank you for choosing Fren. & (b). \\
\hline $\begin{array}{l}\text { (c) Fren is the mobile communications services } \\
\text { Mobile- } 8 \text { that offers you more mobility and } \\
\text { flexibility in your daily activities through our } \\
\text { wireless communications and rich multimedia } \\
\text { services. }\end{array}$ & $\begin{array}{l}\text { (c) Fren adalah layanan komunikasi selular dari } \\
\text { Mobile- } 8 \text { yang memberi anda kelebihan dalam } \\
\text { bermobilitas dan keleluasaan dalam melakukan } \\
\text { aktivitas bergerak melalui layanan komunikasi nirkabel } \\
\text { dan beragam layanan multimedia. }\end{array}$ \\
\hline $\begin{array}{l}\text { (d) By adopting the 'next generation' of mobile } \\
\text { communications technology, Fren network is } \\
\text { capable of providing you better quality voice calls, } \\
\text { and much faster data transfer. }\end{array}$ & $\begin{array}{l}\text { (d) Menggunakan teknologi komunikasi bergerak } \\
\text { 'next generation', jaringan yang dimiliki Fren } \\
\text { menghadirkan kualitas yang lebih baik dalam } \\
\text { berkomunikasi suara maupun data. }\end{array}$ \\
\hline
\end{tabular}

- 'Welcome, Fren' was translated into 'Selamat Bergabung, Fren!'. This translation has been accurate and acceptable although there was an addition of word: 'welcome' (one word) into 'selamat bergabung' (two words). In geneanal in Indonesia, the literal translation of the word 'welcome' is 'Selamat datang', but in this context, if it was translated into 'selamat datang', it was neither appropriate nor acceptable because the target text was for the readers. The translation of 'Selamat Datang' would be appropriate and acceptable for welcoming a person or a group of people. Meanwhile, the context above was non-physical. The people who got a wormtth welcome were not only those who had become the fren's customers but also for anybody else or those had not who got a chance to read that text and they were expected to be attracted, then joined and became the new Fren's customers.

- 'Thank you for choosing Fren' was not translated into target language. The writer thought that the translator intentionally did not translate it into target language. In translation theory, the translation result or the target language was not faithful with its source language. However, if it was seen from the whole context, the deletion or omission in the target language did not change meaning and neither did affect anything to the whole meaning of the text because basically, the translation result of 'Selamat Bergabung' that had been stated previously in target language had implied its meaning of gratefulness for choosing 'Fren'.

- In general, the tranlation result of this sentence has been accurate and acceptable although there is a shift in meaning of several words, structure and class of word, such as: a word becomes phrase, as follows:

$>$ 'offer' that means 'menawarkan' (Ind) was translated into 'memberi' (Ind).

$>$ 'mobile communications services' was translated into 'layanan komunikasi selular'. This could happen due to the difference of place structure between source language (text) and target language (text). In source text, adjective precedes the noun modified but in target text, a noun precedes adjective. E.g: high mountain (source text) is translaten into 'gunung tinggi' (target text).

> 'your daily activities' was translated into 'melakukan aktivitas bergerak' (Ind). Here there was an omission or deletion of the words 'your' and 'daily' but it does not change its meaning. Besides, there was also a change of word class and a word addition, that was from the word 'activities' (single noun) was translated into 'melakukan aktivitas bergerak' (verb phrase).

$>$ Our wireless communications and rich multimedia services' was translated into 'layanan komunikasi nirkabel dan beragam layanan multimedia'. Here there was a shift of position (place) due to the different structure between source text and target text. The word 'our' in the source text was also deleted in target text. Meanwhile the word 'rich' was translated into 'beragam'. However in this context it has been accurate and acceptable.

\section{CONCLUSION}

In foreign language learning, comparing the two languages between source language and target language could not be avoided. Therefore to achieve the target, for the first time a teacher usually introduces the new language to learn by using the source language and he does not directly use the target language as a mediium of instruction. By employing this method, step by step the target 
language being introduced and used, most of linguistic aspects and their implementation would finally be well mastered by the learners. This was due to the fact that each language has some differences and similarities dealing with linguistic aspects. Then, later on the language competence of the learners would finally be getting better and better because they find it easier to learn the new language if there are similarities of linguistic aspects between the source language and the target language being learnt. Hence finally, a translator would find it easier also to translate a text if the the source text being translated had similarities of linguistic aspects with those of the target one.

\section{REFERENCES}

[1] Baker, Mona. 1998. 'Routledge Encyclopedia of Translation Studies' . Great Britain. TJ. Internatioanal Ltd; Padstow, Cornwall.

[2] James, Karl. 1980. 'Contrastive Analysis'. England. Longman Group Limited.

[3] Kunardi; 2006. 'Hand Out / Supplement'- Teaching Material of Contrastive Analysis. Surakarta. Universitas Sebelas Maret Surakarta.

[4] Lado, Robert. 1966. Linguistics Across Cultures: Applied Linguistics for Language Teachers. USA: The University of Michigan Press.

[5] Larson, Mildred.L; 1984. 'Meaning-Based Translation' London. University Press of America Inc.

[6] Leaflet 'fren'. 2006. Indosat, Indonesia.

[7] Riccardi, Alessandra. 2002. 'Translation Studies': Perspectives on an Emerging Discipline'. Cambridge, United Kingdom: Cambridge University Press

[8] Richards, Jack C. Platt, John; \& Platt, Heidi. 1993. Dictionary of Language Teaching \& Applied Linguistics. Singapore, Longman.

[9] Soedibyo, Mooryati. 2004. 'Analisis Kontrastif; Kajian Penerjemahan Frasa Nomina'. Surakarta. Pustaka Cakra.

[10] Sorvali, Irma; 1996. 'Translation Studies in a New Perspective'. Berlin, Germany.Peter Lang GmbH.

Citation: Sukirmiyadi. "The Role of Contrastive Analysis in Translation Study" International Journal on Studies in English Language and Literature (IJSELL), vol 6, no.9, 2018, pp. 30-34. doi:http://dx.doi.org/10.20431/2347-3134.0609004.

Copyright: ( ) 2018 Authors. This is an open-access article distributed under the terms of the Creative Commons Attribution License, which permits unrestricted use, distribution, and reproduction in any medium, provided the original author and source are credited. 